\title{
The Emerging Trend of Technological Convergence and Tasks for Science Parks
}

\author{
Byung-J 00 Kang*1 and Deog-Seong $\mathrm{Oh}^{2}$
}

Dept. of Urban Planning and Real Estate Studies, Hannam University, ${ }^{1}$ Dept. of Architecture, Chungnam National University, ${ }^{2}$ Republic of Korea

\begin{abstract}
Many scientists today say that converged technologies, not specifically dedicated technologies, will be in the vanguard in the $21^{\star}$ century. Technological Convergence is the merging of different areas of technology to perform similar tasks. Since we are living in the era of Technological Convergence, it is time for us to think about how to cope with the daily demands we are facing in science parks. Technological Convergence is a mega trend in commercial areas today but, so far, no science parks seem to have tried to reshape their management policies or programs in order to utilize this trend. For the development of science parks we suggest some tasks such as: identify potentials for Technological Convergence, establish a convergent ecosystem by building connections across stove-piped systems, effect a technological convergence platform, and conduct further research for strengthening plans for converging technologies.
\end{abstract}

Keyword: Technological Convergence, Global innovation system, Interdisciplinary standpoint, Competitive priority, Paradigm shift, etc.

\section{BACKGROUND AND TREND OF TECHNO- LOGICAL CONVERGENCE}

\subsection{Background}

Technological innovation through the technological fusion or technological convergence ${ }^{1}$ has recently become one of the hot topics in academia and industry. The Korean government has chosen ten growth engine industries for the next generation. Those which hold high potential, for technological innovation, such as IT, NT, BT, ET, and CT were designated as the five major growth engine industries in the year 2008 .

The appearance of growth engine industries to gain competitive advantage through the technological convergence

*Correspondence to : Byung-Joo Kang

Professor, Dept. of Urban Planning and Real Estate Studies, Hannam University, Republic of Korea E-mail : kbj20@hnu.kr

World Technopolis Review

Copyright $\odot$ World Technopolis Association

CC This is an open-access article distributed under the terms of the Creative Commons Attribution Non-Commercial License(http://creativecommons.org/licenses/by-nc/3.0) which permits unrestricted noncommercial use, distribution, and reproduction in any medium, provided the original work is properly cited has proposed a new agenda for industries, researchers, and governments in searching for a development tool. Creation of new technology and product through the innovation process called 'Technology Convergence', is a world-wide trend today, and this phenomenon has taken place due to the fact that traditional stove pipe technology is too limited to meet the current demands. Bio-informatics converging from information technology and bio-technology is a good example of this. This new area of genetic information technology was created by applying capabilities of storing and analysing from information technology to biology, and there is a strong competition among advanced countries to acquire a competitive advantage in this field.

Traditional researches based on comparative advantage views non-mobile production factors such as natural resources and low cost labour as being highly influential national industrial competitive power(Quandt 1999). Since technology was conceived as a constantly available free

\footnotetext{
1 Johannes, Pennings and Phanish Puranam(2001) differentiated the definition of fusion and convergence. Recombination of already existing technologies to create a synergy effect is core in fusion, however utilizing features of similar technologies from other fields to meet specific needs is core in convergence.
} 
resources, it was regarded as a codified and specialized industrial source for profit maximization for traditional researches. Under the traditional view point, the importance of possible areas for technological convergence was passed over without noticing the feature of distinguished technological capabilities that exist in different industries.

However, another researches based on knowledge-based economies views intangible production factors, for instance, knowledge, as a technological innovation facilitator or a growth engine, and study the exchange of tacit knowledge and codified knowledge which could be an important factor in the technological innovation process (Nonaka and Takeuchi 1995). It is believed that competition between industries, innovation and core technologies is happening through the knowledge exchange and studies among interested parties who have complementary technological competencies. Accordingly, researches based on knowledge-based economies could be used effectively in analysing factors of comparative advantage and motives of technological convergence among industries.

The aim of this paper is to present an overview emerging trend of technology convergence in industry, academia, and governments and to show the benefits of and opportunities for convergence. Three cases of technological convergence were analysed to understand how this mega trend has progressed in each field world-wide. This paper concludes with recommendations for the development of Science Park in general and Daedeok Innopolis in particular.

\subsection{Transition of Technological Convergence and par- adigm shift}

Convergence is a mega trend across every technology and every product world-wide today. However, convergence is still progressing from the unitary disciplinary stage to the technological boundary destruction stage.

Traditional technology was material oriented and under the auspices of a National Innovation System was unitary-disciplinary and took a macro-systematic approach. Research on traditional technologies was conducted in a unitary-disciplinary manner and stove-piped technologies were the research targets but only remarkable changes received a good response.

Current technology is information oriented and under the auspices of a Regional Innovation System and is dual-discipli- nary and takes a micro systematic approach. Researches on current technologies is conducted in an interdisciplinary or multidisciplinary manner and converging technological convergence receives a higher grade.

New converging technology will be knowledge oriented and under the support of a Global Innovation System will be multi-disciplinary and will take a nano systematic approach. Researches on converging technologies will be conducted in a situation of destruction of technological boundaries. Overlapping of lateral technological convergence will be the research targets but common revolutionary advances will be highly evaluated.

Technological innovation through the technological convergence is not only happening via collaboration among similar industries but also via collaboration among lateral industries. Therefore, to adapt to transition of technological convergence, it is important to search new technological innovation through networking between lateral industries and same kind and lateral inter-linking.

Acquisition of competitive priority in newly converging industries is achieved through the collaboration and networking among industries which hold various technologies. Knowledge shared and developed like this is conceived as a collective asset not a by-product of technological innovation and accelerates new technology convergence and new products. In other words, a paradigm shift based on technological convergence is not a radical change in technologies or industries but has a self-organizing feature because it happens through the continuous and accumulated co-evolution of existing paradigms (Dawid and Wersching 2006).

Convergence revolution is a paradigm shift, but not just, in Thomas Kuhn's terms, a paradigm shift within a discipline(Sharp 2011). Convergence implies a broad rethinking of knowledge bases. The convergence revolution does not rest on a particular scientific enhancement but on a new integrated way for achieving enhancements.

Convergence in the ICT area has progressed over many years. In fact, it is as old as the ICT industry itself. The history of this industry reveals how progress was developed, and the process of recombination of different technologies in ICT fields(Bacharach 2008) ${ }^{2}$.

You may remember that telephone, print media, film, radio, TV and computer data were treated as separate technologies. Over the last many years, technological conver-

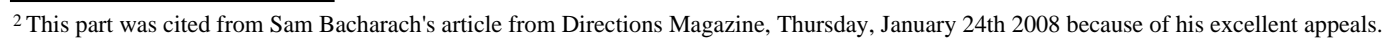


gence has resulted in a new generation of multimedia communication products.

Similarly, in the geo-spatial industry, there was a time when remote sensing, GIS, CAD, AM/FM and navigation were different vertical markets served by different technological providers. Now these various geo-enabled technologies are converging and their respective markets are becoming more horizontal. In order to survive in this dynamic and competitive market, software dealers are working to break down the old market stove-pipes. Stove-pipe solutions in the geospatial industry are now seen as simply artifacts of each technology's inherent obstacles.

\section{THEORETICAL REVIEW ON TECHNOLOG- ICAL CONVERGENCE}

\subsection{Definition of convergence and Technological Convergence}

Convergence is defined many ways depending on the subject. It is the merging of distinct technologies, processing disciplines, or devices into a unified whole that creates a host of new pathways and opportunities. Convergence is advanced with the coming together of different fields of study through collaboration among researchers and the integration of approaches that were originally regarded as contradictory(Sharp 2011). Convergence in ICT field is very common for the sake of convenience of users like combining two or more different technologies in a single device. Taking pictures with a cell phone and surfing the Web on a television are two of the most common examples of convergence in ICT area.

However convergence is expressed in many different ways. Convergence means the notion that some functions and sequences approach a limit under certain conditions in mathematics. However in sustainability science, convergence means progress towards equity within biological planetary limits. In the case of telecommunications, convergence means a combination of multiple services through lines of telecommunication from a single provider(from Wiki's). Technological convergence in ICT area is the convergence of different arrays of technology to perform similar tasks.
Convergence, in this case means the synergy oriented combination of different forms of information such as voice, video, and data onto a single network. The combination of different communication technologies such as above create new efficiencies. An example of a technological convergence is the cell-phone(ccit, convergence). Cell-phones are no longer only used to communicate from one person to another, but are now capable of playing MP3's, take pictures, capture videos etc. As technology improves, so does the quality of these tools.

\subsection{Benefits and opportunities of Technology Convergence}

Technological convergence could provide many benefits and opportunities over many areas. In general, convergence plays an important role in society from economic, social, and development perspective(Wong 2005). It can influence the way in which governments develop appropriate policy while looking for social welfare, enterprises compete in the market, and individuals communicate with each other and benefit from efficient and lower-cost, innovative and new valueadded products and services. In this sense, technological convergence brings new opportunities to meet development goals and bridge the digital divide ${ }^{3}$ a single service provider can offer different products and services ${ }^{4}$.

Technological convergence has two aspects such as technical and developmental. It has different meanings according to aims, interests, and roles of different stake-holders such as policy-makers, researchers, public society and private sector. The opportunity arises to obtain equilibrium of interests and to increment understanding and awareness among them through adequate communication channels (Wong 2005), multi-stakeholder dialogue and participatory cooperation.

Technological convergence along with standardization ${ }^{5}$ enables transparent and modular communication between different products over the network and the possibility of delivering a broader set of them as a broader set. Therefore, manufacturers and software programmers can work in different but coordinated ways (UN 2005).

Other benefits are lower entrance barriers, promotion of competition, lower cost equipment, quicker market response (Malcom 2006), and new business opportunities.

\footnotetext{
${ }^{3}$ Both technological and media or content convergence end up reaching the consumer.

${ }^{4}$ Regarding convergence in the media for example, for the customer it means more features in less space, and for the providers it means remaining competitive for keeping market dominance or presence.

${ }^{5}$ Best experiences in standardization began in the software development.
} 
In addition to the evolution of infrastructure, privatization, liberalization, and competition telecommunications evolved in response to trends in globalization. There is an interaction among globalization, public policy and governance. It means that public policy shapes globalization, and globalization shapes governance, innovation and changes in technology affect competition and globalization and will influence a generation of new public policy issues which will generate new consideration in governance(Arenza 2011).

Technological convergence can play an important role in national economic and social development of every country, especially in the fields of IT industries. Governments can capitalize on the opportunity to stimulate market development and meet previous unmet social needs. Technological convergence offers massive opportunities for the development of new value-added services, convenience, efficiency and the expansion of markets and consumer choice. Three opportunities are found from technological convergence in ICT industry (Papadakis 2009).

Convergence has lowered barriers of entry to the market for new operators and service providers. The emergence of new market players intensifies competition, giving consumers an extensive pool of providers and services to choose from and lower communication costs.

Additionally in a technological convergent environment, industry boundaries become blurred, allowing service providers to offer services in multiple markets. For example, besides access to television, cable operators can also offer voice telephone and internet services. Content providers can now easily access consumers with no need to own the distribution network. For example, a company may produce TV content and distribute it through cable networks without having to own it(Papadakis 2009).

New services and applications could emerge from technological convergence. Established companies will find in convergence an opportunity to operate more efficiently, increase returns on technological investments and realize other business benefits through development of new services and rapid market expansion. Convergence opens up new sales markets for companies, a case observed in mobile operators. As the market saturates, they look to non-voice services, such as video streaming, portals, messaging, information services, and gaming to drive future revenue growth.

New applications have given rise to new ways of entertainment such as online gaming and socialization such as chat rooms. The convergence of voice, video and data gives con- sumers new ways of communication as we can all talk, send text and video over one single network, using one single application at much lower costs than before(Papadakis 2009).

At device level, consumers find in convergence an opportunity to enjoy the convenience of having many devices all in one, saving on both size and ownership costs. For example, a single mobile phone device can receive television programms and play videos, thus enabling simplicity and convenience in device ownership as one device can be used to access multiple services(Papadakis 2009).

\subsection{Challenges caused by Technological Convergence}

The biggest challenges brought about by technological convergence are identified in the policy and regulatory arena involving concerned stake-holders.

Concerning the policy arena, technological convergence faces the challenge of reaching and protecting public interests, and avoiding being used politically and artificially to protect vertically integrated markets by the broadcasters and their regulators (Shin 2006). Concerning the regulatory arena, regulators have to respond to technological innovations and deal with changes in their frameworks and legislation (Jerome 2005). This requires a transition to a crossproduct, cross-platform and cross-sectional licensing.

Participating stake-holders are also directly facing some challenges; on the one hand, network operators must be increasingly competitive, e. g. by transforming their traditional infrastructure and circuit switched network into a more efficient packet switched one. On the other hand, in order to deliver value-added products and services operators need to provide applications, services and content which fit the demands, location and preferences of users at reasonable prices in suitable markets on the other hand. This supply should be done through flexible and open-architecture technologies and equipment. This equipment should contain core features flexible enough to support upgrades and scale-ability. On the software side, providers have to look for better ways to store and access information in a safe and rapid way. ${ }^{6}$ Governments aim is to find equilibrium and avoid asymmetry in favour of the less regulated services. Similarly, socio-ethical difficulties arise regarding oversight, transparency, and surveillance acts or abuses, as well as ways to handle the unawareness of stake-holders.

In relation to markets, since they are becoming smaller within countries, it is necessary to look for others and to try to gain the advantages of economies of scale. Countries have 
to look for regional markets. In addition, technological convergence threatens universal service ${ }^{7}$ funding systems; and regarding cyber-security, policies have an essential role to play to overcome mobile security threats, theft and phishing, and denial of service attacks.

In addition, aiming to ensure interoperability, modularity, and flexibility, providers are confronting the difficulties of standardization and harmonization through cooperation and participation of industry players. ${ }^{8}$ Among other important challenges; technological neutrality requires working on initiatives aimed at lowering barriers for adoption of technological convergence and infrastructure facilitation (Jerome 2005).

Focus and priorities of each country regarding adoption of technological convergence require technical capacities within the countries, especially in developing countries, through international cooperation and incorporation of the best practices of developed countries. ${ }^{9}$ Finally, it is important to consider not only the dynamic interaction among the technological, political and market areas, but also the difference in speed of changes each of them has. Technological innovation is more dynamic than the competition dynamic of the market and it is more dynamic than the adequacy and stability of public policy and the legal framework.

\section{CASE STUDIES OF TECHNOLOGICAL CONVERGENCE}

Three case studies are conducted in this paper, because in areas such as IT, BT, and NT technological convergences are frequently observed in any society. However, it should be noticed that the technological regimen between IT, BT and NT is each different. IT could be easily converged with other technologies because it could be used as a tool. However, BT has its' own market because BT is more specific goal oriented and is used for curing diseases or revitalizing patients. NT, does not have its' own technological area, therefore it could be used as a platform for the maximization of synergy effect for other technologies. Accordingly, NT could be easily converged with IT, BT and CT(cognitive technology) etc.

\subsection{Information and communication (from wiseGEEK) $^{10}$}

Technological convergence is the trend of technologies to merge into new technologies that bring together a myriad of media. While historically, technology handled on medium or accomplished one or two tasks, through technological convergence, devices are now able to present and interact with a wide array of media.

In the past, for example, each entertainment medium had to be played on a specific device. Video was played on a television by using a video player of some sort, music was played on a tape deck or compact disc player, radio was played on an AM/FM turner, and video games were played through a console of some sort. Similarly, different communication media used their own technologies. Voice conversation was transmitted by telephone, video communication briefly used high-end video phones, facsimile copies used fax machines, and e-mail used a computer.

Technological convergence in the past few years has resulted in devices that not only interact with the media they are primarily designed to handle, but also with a number of other formats. For example, most modern DVD players are capable not only of playing DVDs, but also of playing music CDs, displaying photos from CDs, playing encoded video in formats such as DIVX or VCD, and playing DVD music.

Technological convergence also leads to devices that are designed specifically to replace a number of different devices. The Apple iPod ${ }^{\mathrm{TM}}$, for example, while originally conceived of as a portable music player, is now touted equally as a portable video player, photo album, and radio tuner. Cell phone, as well, have moved far beyond their beginnings as simple voice communication device and now offer the functionality of personal music players, digital cameras, and text messenger systems as well.

The Internet is perhaps the most widespread example of

\footnotetext{
6 Some of the disadvantages of technological convergence regarding new devices are found in their initial forms, as for example converged devices are less functional and reliable, and more prone to problems that could discourage end users, however tendencies show that a wide range of technologies are converging into single multipurpose devices. Other impediments could be storage space, power supply, battery, capacity, complexity.

7 It is recommened to consider universal access and service in terms of five components: infrastructure, services, cost, maintenance and upgrade.

8 Some issues such as proprietary incompatibilities or non adoption of standards are difficult to overcome.

9 The implications of technology and market convergence on regulation has been different depending on the focus and priorities of each country or block of countries, for example the US has focused enhancing competition in the delivery of similar services by different networks, and in the finding of solutions created by horizontal integration. On the other hand Europe has focused on the societal advantages in forms of new services, applications, industries and devices.

10 wiseGEEK is a magazine where about 200 researchers, writers and editors are dedicated to providing short, clear and concise answers to common questions.
} 
technological convergence. Virtually all entertainment technologies - from radio to television to video to books to games - can be viewed and played online, often with greater functionality than they had in their primary technology. Communications technologies, as well, can be used with the internet replacing fax machines, telephones, video phones, and the postal service.

While technological convergence gives consumers the convenience of having many devices all in one, saving on both size and cost, there is an initial trade-off in quality. When technological convergence first gives birth to a new multitechnology, the various technologies of which it is comprised usually perform at a slightly lower standard than independent devices. Usually within a year or two, however, this disparate quality is reduced to a virtually unnoticeable level.

\subsection{Medical devices}

The medical products industry has repetitively experienced technological convergence. The convergence has included some diagnostics imaging tools such as X-ray technology, ultra imaging, and Magnetic Resonance Imaging to the more recently developed Quantum Dot Imaging. Point of care devices such as blood test strips, optical blood glucose meters, followed by portable blood glucose meters are additional examples of medical products technological convergence (Wilkinson 2006).

One of the product families created by the convergence of piezoelectric material science, microelectronics and computer image processing was ink jet printing, another was ultrasonic imaging. Ultrasonic imaging is a good examples of technological convergence that benefited human health. It is a non-invasive method of investigating various soft tissue organs such as the heart, liver, gallbladder and kidneys.

Ultrasonic imaging is most commonly associated with obstetric where it is used as a tool for monitoring and evaluating pregnancies. In early in a pregnancy, it is used for diagnostics and confirmation. As the pregnancy continues it is used to determine gestational age and assess the fetal size. It is also used to detect multiple pregnancies and fetal malformations. One of its more controversial is that of gender selection, where individuals decide to continue or terminate the pregnancy based on the fetal gender. As a new technological convergence comes into existence, society faces new ethical dilemma.

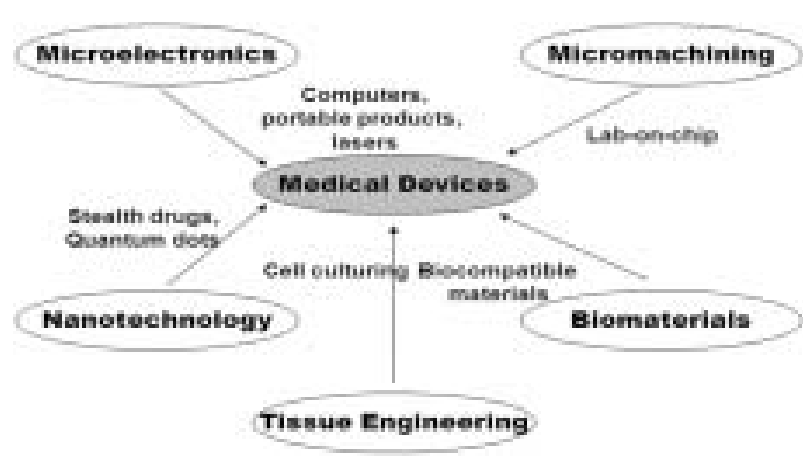

Fig. 1. Technological convergence in medical devices Source: Wilkinson, J. M.(2005) Future Areas of Technological Convergence

\subsection{Nano-technology(Roco 2002)}

The convergence of nano-scale science with modern biology and medicine is a trend that should be reflected in science policy decisions, because convergence of nano-technology, biotechnology, info-technology and cognitive sciences is based on material and scientific unity at the nano-scale. Nano-bio-technology is defined as a field that applies the nano-scale principles and techniques to understand and transform bio-systems (living or non-living) and which uses biological principles and materials to create new devices and systems integrated from the nano-scale.

The integration of nano-technology with biotechnology, as well as with info-technology and cognitive science, is expected to accelerate in the next decade.The nano-scale assembly of organic and inorganic matter leads to the formation of cells and to the most complex known systems - the brain and human body. Nanotechnology plays a key role in understanding these processes and in the advancement of biological sciences and biotechnology.

Nano-scale and bio-systems research are merging with info-technology and cognitive science leading to completelynew science and technological platforms such as those for genome pharmaceutics, bio-systems on a chip, regenerative medicine, neuroscience, and food systems.

Nano-technology offers new solutions for the transformation of bio-systems and provides a broad technological platform for applications in several areas such as bio-processing in industry, molecular medicine, investigating the health effect of nano-structures in the environment, improving human performance etc. 


\section{TECHNOLOGICAL CONVERGENCE FROM SCIENCE PARK IN KOREA}

\subsection{Trend of Technological Convergence in Korea}

The core of Korean economy has changed substantially over the last 60 years. In the 1940s, the country was predominantly agricultural. The emphasis shifted to light industry and consumer products in the following decades and then to heavy industry in the 1970s and 1980s. During this period, Korean economy grew enormously and the economic structure was radically transformed. The economy matured rapidly during the 1990s and the exponential growth rate finally started to slow down. Recently, Korea aims to become the world's leading IT nation and to some extent has succeeded.

The lack of basic science and source technologies is creating a gap in convergence technologies with developed nations. Korea's convergence technology, which remains at the beginning stage, is $50 \sim 80 \%$ that of advanced countries (Lee 2009).

As a global trend, technological convergence policies are being pursued to maximize the ripple effects on society. The Korean Government established an ambitious plan on technological convergence such as "National Plan for Development of Convergence Technologies during 2009 2013". This plan was prepared jointly by seven departments from the central government. The Korean government regards technological convergence as a global trend so it has established a comprehensive plan to cope with this mega trend. The Korean government seems to consider that the next generation of thechnological revolution will occur through the converging of technologies such as IT, BT, and NT all together.

In contrast, Korean - supply considers technological convergence as a tool for technological innovation to promote policies focusing on the short-term market performance of related industries. Among the 400 Convergence Technology R\&D Projects implemented by the Ministry of Knowledge Economy in 2007, IT accounted for 104 projects, BT, 247 projects, NT, 17 projects, and ET, 24 projects. This shows that Korea - which has a technological gap in NT and ET compared to more advanced countries, - is not investing enough in converging technology R\&D in these two areas(Lee 2009).

\subsection{Current situations in Daedeok Science Park}

There are many world-class research institutes in Daedeok Science Park such as the Electronics and Telecommunications
Research Institute, Korea Atomic Energy Research Institute, National NanoFabCenter, Korea Aerospace Research Institute etc. that are focused on biotechnology, nano-technology, and satellite technology. There has been a big change in composition of organizations in Daedeok Science Park over the last seven years. In 2003 there were 247 occupants in Daedeok Science Park divided as follows: 18 government research institutes, 7 support agencies, 9 public organizations, 38 private research labs, 4 universities and 171 firms. Deadeok Science Park did not offer a highly favourable environment for the exchange of information and knowledge on science and technology on IT, BT, and converging technologies in the year 2003.

However Deadeok Science Park currently offers a highly favourable environment for the exchange of information and knowledge on science and technology. Today, Daedeok Science Park consists of a cluster of firms that represents Korea's leading industries in the field of IT, BT and NT .

Table 1. Number of organizations in Daedeok Science Park

\begin{tabular}{l|r|r}
\hline \multirow{2}{*}{ Organizations } & \multicolumn{2}{c}{ Numbers } \\
\cline { 2 - 3 } & Year 2003 & Year 2010 \\
\hline Government Research Institutes & 18 & 29 \\
\hline Support Agencies & 7 & 8 \\
\hline Public Organizations & 9 & 14 \\
\hline Private research labs & 38 & 27 \\
\hline Universities & 4 & 5 \\
\hline Firms & 171 & 1,006 \\
\hline Total & 247 & 1,089 \\
\hline
\end{tabular}

Source: Daedeok Innopolis(2003, 2010), Current status of Daedeok Science Park.

There are currently 1,089 occupants in Daedeok Science Park. Those occupants are divided into 29 government research institutes, 8 support agencies, 14 public organizations, 27 private research labs, 5 universities and 1,006 private firms. Table 2 . shows the classification of all the research institutes and firms based on technological types. Among seven technology groups, IT related occupants and converged technology related occupants are the major ones, and space related technology occupants hold second major place. Many technologies are included in 'the other' technology classification even if the number of that group is the largest in Daedeok Science Park.

Research institutes located in Daedeok Science Park are focused on five technologies such as IT, BT, NT, ST, and converged Technology. R\&D institutes of converged technology are the major institutions in Daedeok Science Park. And that is why Daedeok Science Park is called an applied science park. R\&D institutes of information technology and 
Table 2. Number of firms and R\&Ds based on technological classifications

\begin{tabular}{c|c|c|c|c|c|c}
\hline & Firms & $\begin{array}{c}\text { Government } \\
\text { Research Institutes }\end{array}$ & $\begin{array}{c}\text { Public } \\
\text { Organizations }\end{array}$ & $\begin{array}{c}\text { Educational } \\
\text { Institutions }\end{array}$ & $\begin{array}{c}\text { Other Nonprofit } \\
\text { Organizations }\end{array}$ & Total \\
\hline IT & 208 & 4 & & & & $212(19.4)$ \\
\hline BT & 62 & 2 & & & & $25(5.8)$ \\
\hline NT & 24 & 1 & & & & $86(7.9)$ \\
\hline ET & 86 & 9 & & & & $11(1.0)$ \\
\hline ST & 3 & & & & & $3(0.3)$ \\
\hline CT & 196 & 5 & & & & $201(18.4)$ \\
\hline Converged T & 418 & 9 & & & & $427(39.2)$ \\
\hline Other T & 1,006 & 23 & 20 & 8 & & $1,089(100.0)$ \\
\hline Total & & & & & 33 \\
\hline
\end{tabular}

Source: Revised from Daedeok Innopolis(2010), Current status of Daedeok Science Park.

nuclear and atomic related technologies are the second major institutions.

Currently about 196 firms holding convergence technologies are located in Daedeok Science Park. About 131 firms with IT based convergence technology are the major group, and secondary major groups are BT based 27 firms and NT based 20 firms. Therefore, Daedeok Science Park is concentrated with IT, BT, and NT areas in terms of technological convergence.

\subsection{Directions for the development of Daedeok Science Park}

Daedeok Innopolis is the organization managing Daedeok Science Park. It provides basic infrastructure such as electricity, power, water, sewerage services etc. to the firms and research institutes located in the park. There are currently two divisions and one center in DaedeokInnopolis. Division of Strategic Planning takes care of administrative affairs of the Park in general and holds one global cooperation team. International exchanging programs such as "Workshop for Korean STP Model" or "Exchange program of science park expert" etc. are under the supervision of this division. Division of business support designates high-tech firms to the Park and plans site development. It also provides many services to the entities in the Park such as conducting education, welfare and events, and conducts a variety of promotion activities for the Daedeok Science Park.

Table 3. Job descriptions of each office in DaedeokInnopolis

\begin{tabular}{|c|c|c|}
\hline Upper-level division & Sub-level office & Jobs in charge \\
\hline \multirow{2}{*}{ Division of Strategic Planning } & Strategic Planning Team & $\begin{array}{l}\text { Regulation, administration, finance, for DaedeokInnopolis } \\
\text { Operating evaluation system for projects }\end{array}$ \\
\hline & Global Cooperation Team & $\begin{array}{l}\text { Workshop for Korean STP Model } \\
\text { Operating international exchanging programs }\end{array}$ \\
\hline \multirow{3}{*}{ Division of Business Support } & Management Supporting Team & $\begin{array}{l}\text { Managing property, facilities etc. of Daedeok Science Park } \\
\text { Conducting education, welfare and event, etc. }\end{array}$ \\
\hline & Infrastructure Building Team & $\begin{array}{l}\text { Designating high-tech firms } \\
\text { Managing commercialization zone } \\
\text { Planning site development }\end{array}$ \\
\hline & Promotion and Networking Team & Promoting Daedeok Science Park and networking jobs \\
\hline \multirow{2}{*}{$\begin{array}{l}\text { Center for Technology } \\
\text { Commercialization }\end{array}$} & Business Planning Team & $\begin{array}{l}\text { Technology transfer } \\
\text { Managing R\&BD projects in Bio-medical areas } \\
\text { Managing technology trust project }\end{array}$ \\
\hline & $\begin{array}{l}\text { Technology Commercialization } \\
\text { Team }\end{array}$ & $\begin{array}{l}\text { Supporting manufacturing experimental products } \\
\text { Supporting marketing activities } \\
\text { Conducting education for technology commercialization }\end{array}$ \\
\hline
\end{tabular}


There are two teams under the Center for Technological Commercialization. Technologies generated by the Park are transferred and R\&BD projects in bio-medical areas are carried out by the Business Planning Team. A Technological Commercialization Team supports marketing activities and conducts education for technological commercialization. However no team or division exists to handle technological convergence as yet. Since technological convergence is a mega trend that Daedeok Science Park could not escape, it is better to be ready in advance.

But as previously noted in this paper the phenomenon of technological convergence is already in use in the Park. Therefore, actions should be taken to cope with this new mega trend. Some actions include identifying potentials for technological convergence, building connections across stove-piped technology supporting programs, conducting further research for strengthening platforms for developing technological convergence, and educating, and supporting the next generation of convergence researchers. These actions are described in more detail in the next section

\subsection{Recommendations for Technological Convergence in Daedeok Science Park}

Five, suggestions are recommended for the advancement of technological convergence in Daedeok Science Park but those five could be applied to any science parks in the world.

First, initiation of technological convergence starts with identification of potentials for technological convergence, and to do this, it is necessary to identify technological convergence trends within the sub-sectors is necessary. Involvement of firms and mediating organizations(universities, science parks, sector organizations) in application-oriented testing activities and with a commercial perspective are absolutely needed in the Daedeok Science Park.

Second, establishment of a convergence ecosystem by building connections across stovepiped systems is required. In most countires scientific research has historically been funded in separate stove-pipes by science-mission agencies. In areas where collaboration can be highly productive, funding agencies, not just scientists, but administrators should become collaborators. That means talking to one another, jointly identifying the areas of greatest opportunity as well as the primary scientific challenges, and developing common strategies for progress.

Some joint researches projects between inter institutions are carried out in Daedeok Science Park, but such projects seem to depend on informal friendships or on slowly established working relationships between individuals in various institutions. It is better to build mechanisms to enable and foster such connections under the aegis of law or regulations of the institutions.

Third, establishment of a platform for technological convergence is needed. It is necessary that this be based in a mediating organization and supported by the regional governments in the Daedeok Science Park. Linking clusters and networks from different sectors and technologies with a potential for developing technological convergence application with a global commercial potential is also very important. DaedeokInnopolis is believed to perform this role properly.

Fourth, conducting further research for strengthening platforms for converging technologies is an important task. To achieve this, linking existing clusters and networks among WTA member cities could be a starting point of further research in strengthening platforms for converging technologies. As can be seen in previous analyses, firms that hold converging technologies composed of $18.4 \%$ of Daedeok Science Park. Therefore, focusing on shared opportunities within technological convergence in the field of IT technology, biotechnology and nano-technology could be another starting point for further research. Building a platform on existing clusters and existing networks could be an appropriate way of building a platform for technological convergence.

Fifth, high educational institutes such as universities and research institutes now understand that the integration of scientific and engineering technologies is a reality and technological convergence will be the future of bio and IT related enterprises. New efforts must be undertaken to educate the next generation of researchers to work in cross-disciplinary fields. While a strong disciplinary background remains vital, including a robust cross-disciplinary education is essential additional preparation for our future scientists and important for research careers.

\section{CONCLUSION}

Compared to the rate of development of science and technology during the 17th-19th cenuries, the rate of development of science and technology in the $21^{\text {st }}$ century is dazzling. Since quantum physics opened a new way of looking at the microscopic world and the universe, science and tech- 
nology have advanced at an unprecedented speed. As a result, we are now on the verge of manipulating objects and devices in nano-scale. Such a developmental rate will be accelerated in the future due to the synergy effects of interdisciplinary research and technological convergence.

Technologies in material science and engineering areas such as physics, chemistry and biology advanced at an amazing rate continuously in the 20th century. Many scientists today believe that converged technologies, not technologies in separately dedicated technologies, will lead the $21^{\text {st }}$ century. The concept of technological convergence that was unfamiliar with in the 20th century was expanded by Ph.D. Roco and Bainbridge in the year 2002 in the report titled "Converging Technologies for Improving Human Performance: Nano-technology, Biotechnology, Information Technology and Cognitive Science."

Roco and Bainbridge predicted that we were entering a new renaissance of science and technology. They asserted that since science developed from single disciplines had reached it's limit, a converged and systematic paradigm shift was required and that convergence would be accelerated due to the accumulated common knowledge that could be applied to individual disciplines. For many years in advanced countires science parks have played a key role in leading national development and working as an growth engine.

Science Parks world-wide are now facing a new trend, called 'Technological Convergence' without a strategy to cope with this wave. Since individual parks may hold different positions, no unified strategy is currently available. However, some actions such as identifying technological convergence potentials, establishing a platform, conducting further research for strengthening platforms, and educating and supporting the next generation of convergence researchers would be necessary in any science parks in the world.

This paper aimed to overview the emerging trend of technological convergence in industry and science parks and to suggest a few recommendations for the science parks in general and Daedeok Science Park in particular. Three cases of technological convergence were analyzed with industrial field basis such as IT, BT and nano technology etc. However this paper is weak in terms of theoretical basis and empirical evidence in suggesting some recommendations for the advancement of technological convergence in the science parks. Therefore further research on gathering empirical evidence of technological convergence in industry is needed.

\section{REFERENCES}

Arenza, S.(2011) "What is technological Convergence?" Wikipedia available at http://en.wikipedia.org/wiki/ Technological_convergence

Bacharach, S.(2008) "Technology Convergence, Market Horizontalization and, Voila: Information Fusion," D irections M agazine, Thursday, January 24th 2008. available at http://www.directionsmag.com/articles/ technology-convergence-market-horizontalizationand-ivoilai-information-fus/ 122770

DaedeokInnopolis(2010) Current status of D aedeok Science Park, 11-16.

Dawid, H. and Wersching, K.(2006) "On Technological Specialization in Industrial Clusters: An Agent-based Analysis" available at http://www.wiwi.uni-bielefeld.de/ fileadmin/vpl1/Dawid_Wersching.pdf

Deonandan, R.(2001) "Biosensors, Biophotonics, Biomaterials and Nano-technology: From Convergence to Cash," BioA lberta N ew sletter(C algary, AB ) June, 2001

Gartner Group.(2003) T echnology convergence driving business model collision, 7-11.

Jerome and SANCHEZ Bernand.(2005) "Technological convergence and regulation, Challenges facing the developing countries," InfoDev Information for Development Program.Accessed October 12, 2011,

http://www.infodev.org/files/2985_file_Communication _and_Strategies.pdf

Lee, Sang-Gyu, Jos, Youn-Ae, and Park, Jong-Bok (Aug. 26. 2009) KIE T N ews Brief.

Nonaka, Ikujiroand Takeuchi, Hirotake(1995) T he K now ledge creating company: $\mathrm{H}$ ow Japanese companies areate the dynamics of innovation. New York: Oxford University Press, 124-131.

Papadakis, Stelios (2009) T echnological convergence: O pportunities and Challenges, 2-3.

Pennings, Johannes and Puranam, Phanish(2001) "Market Convergence and Firm Strategy: new directions for theory and research." E CIS C onference, TheF uture of Innovation Studies, Eindhoven, Netherlands, 19-22.

Quandt, Carlos(1999) Developing Innovation Networks for Technology BasedCluster: The Role of Information and Communication Technologies. Workshop T echno - R egions: Science, technology and R egional D evelopment - Past, Present and $\mathrm{F}$ uture $\mathrm{C}$ hallenges. Rio de Janeiro, 19-26.

Roco MC, Bainbridge WS (Eds) (2002): Converging T echnologies 
for Improving H uman Performance. N SF - D OC R eport, Kluwer: Boston. Accessed October 16, 2011,

URL: http://wtec.org/ConvergingTechnologies

Santosa, Setyanto P. (2000) "Benefits and opportunities of Technology Convergence to the Private Sectors." Accessed October 13, 2011, http://www.pacific.net.id

Shin, Dong-Hee. (2006) "Convergence of telecommunications, media and information technology, and implications for regulation," The Journal of Policy, regulation and strategy for T elecommunications, 8(1); 42-56.

Sharp, Phillip A. (2011) Convergence is a new paradigm that can yiedd critical advances in a broad array of sectors, from health care to energy, food, dimate, and water, MIT Washington Office.

Telekom Austria AG.(2005) "Manifestations of Convergence" Accessed October 12, 2011, http://connect- world.com/ Articles/old_articles/12Manifestationsof Convergence.html United Nations, (2005) R eforming Internet Governance: Perspectiv efrom theW orking $G$ roup on I nternet Governance (WGIG), 31-34.

Wilkinson, J. Malcom. (2006) "Cultivate technology Convergence for ProductInnovation," M edical D evice T echnology, 17(3); 16-19.

Wilkinson, J. Malcom. (2005) "Future Areas of Technology Convergence," Accessed October 16, 2011,www.tfiltd.co.ukwiseGEEK (Free Magazine).

Wong Poh-Kam and Annette Singh. (2005) "Technological Specialization and Convergence of Small Countries: The case of the late-industrializing Asian NIES," NUS Entrepreneurship Center Working paper, 5-11. 